\title{
Review
}

\section{Social modulation of androgen levels in male teleost fish ${ }^{\text {ir }}$}

\author{
Rui F. Oliveira ${ }^{\mathrm{a}, *}$, Katharina Hirschenhauser ${ }^{\mathrm{a}}$, Luis A. Carneiro ${ }^{\mathrm{a}}$, Adelino V.M. Canario ${ }^{\mathrm{b}}$ \\ ${ }^{a}$ Unidade de Investigação em Eco-Etologia, Instituto Superior de Psicologia Aplicada, R. Jardim do Tabaco 34, 1149-041 Lisboa, \\ Portugal \\ ${ }^{\mathrm{b}}$ Centro de Ciências do Mar, Universidade do Algarve, Campus de Gambelas, 8000-810 Faro, Portugal
}

Received 27 January 2001; received in revised form 1 May 2001; accepted 11 May 2001

\begin{abstract}
Androgens are classically thought of as the sex steroids controlling male reproduction. However, in recent years evidence has accumulated showing that androgens can also be affected by the interactions between conspecifics, suggesting reciprocal interactions between androgens and behaviour. These results have been interpreted as an adaptation for individuals to adjust their agonistic motivation and to cope with changes in their social environment. Thus, malemale interactions would stimulate the production of androgens, and the levels of androgens would be a function of the stability of its social environment ['challenge hypothesis', Gen. Comp. Endocrinol. 56 (1984) 417]. Here the available data on social modulation of androgen levels in male teleosts are reviewed and some predictions of the challenge hypothesis are addressed using teleosts as a study model. We investigate the causal link between social status, territoriality and elevated androgen levels and the available evidence suggests that the social environment indeed modulates the endocrine axis of teleosts. The association between higher androgen levels and social rank emerges mainly in periods of social instability. As reported in the avian literature, in teleosts the trade-off between androgens and parental care is indicated by the fact that during the parental phase breeding males decreased their androgen levels. A comparison of androgen responsiveness between teleost species with different mating and parenting systems also reveals that parenting explains the variation observed in androgen responsiveness to a higher degree than the mating strategy. Finally, the adaptive value of social modulation of androgens and some of its evolutionary consequences are discussed. (C) 2002 Elsevier Science Inc. All rights reserved.
\end{abstract}

Keywords: Androgens; Behaviour; Challenge hypothesis; Mating system; Parental care; Social modulation; Teleost fish

\section{Social modulation of male androgen levels: the challenge hypothesis}

Androgens are among the main hormones involved in male reproduction in vertebrates.

\footnotetext{
This paper was submitted as part of the proceedings of the 20th Conference of European Comparative Endocrinologists, organised under the auspices of the European Society of Comparative Endocrinology, held in Faro, Portugal, September 5-9, 2000.

*Corresponding author. Fax: +351-21-88-60-954.

E-mail address: ruiol@ispa.pt (R.F. Oliveira).
}

Extensive evidence suggests a role for androgens in spermatogenesis, in the development of secondary sex characters, and in the expression of reproductive behaviours (for a review see Nelson, 1994). Many studies in different vertebrate groups have shown the activational (or permissive) role of androgens in the expression of male social behaviours, both sexual and aggressive. However, in recent years evidence has accumulated showing that androgens are not only a causal factor for reproductive behaviours but that they may also be 
affected by the interactions between conspecifics suggesting a two-way relationship between androgens and behaviour (Villars, 1983).

Several studies have shown effects of social interactions on the short-term modulation of androgen circulating levels. For example, in mammalian males (including humans) copulation induces a rise in the circulating levels of testosterone (T) and luteinising hormone (LH) (Harding, 1981). Furthermore, in rodents simple exposure to a female or to her odour is sufficient to activate this response (Harding, 1981). In teleost fishes male salmonids, for example, show a rise in sex steroid and gonadotrophin levels and an increase in milt production in the presence of ovulated females (Liley et al., 1986, 1993; Rouger and Liley, 1993). Anosmic males in the presence of sexually active females have lower levels of sex steroids and a lower sperm production than males with intact olfactory epithelium, which suggests that chemical signals may play an important role in this social modulation of hormone levels. In cichlid fishes (e.g. Oreochromis mossambicus) males are sensitive to the maturation stage of females, courting more intensively ovulated females (Silverman, 1978) This effect also seems to be mediated by chemical signals emitted by receptive females (Falter and Dolisy, 1989). Male cichlids also experience a rise in 11-ketotestosterone (KT) in response to courtship interactions (Borges et al., 1998).

Agonistic interactions and male-male competition may also induce an endocrine response in the participating individuals, a response especially sensitive with respect to androgens. In different vertebrate groups, including humans, short-term fluctuations of androgen concentrations have been shown to be related to social interactions (Harding and Follett, 1979; Eberhart et al., 1980; Harding, 1981; Hannes, 1984; Sachser and Pröve, 1984; Hannes, 1986; Sapolsky, 1987; Wingfield and Moore, 1987; Booth et al., 1989; Greenberg and Crews, 1990; Cardwell and Liley, 1991; Oliveira et al., 2001c). However, some studies have also demonstrated that in some cases the levels of aggression and the circulating androgen concentrations are seasonally dissociated (e.g. Dittami and Reyer, 1984; Wingfield and Ramenofsky, 1985; Logan and Wingfield, 1990). It seems as if correlations between androgens and agonistic behaviour are stronger in periods of social instability (challenge), as is the case in the establishment of dominance hierarchies, the foundation of a new territory, the response to territorial intrusions or the active competition with other males for access to females (teleosts: Cardwell and Liley, 1991; Pankhurst and Barnett, 1993; reptiles: Moore, 1986, 1988; aves: Ramenofsky, 1984; Wingfield and Ramenofsky, 1985; Wingfield et al., 1987). In contrast, during periods of social stability the levels of aggression drop to a breeding baseline and dissociation between androgens and aggression may occur.

These results have been interpreted as an adaptive adjustment of the individual agonistic response to changes in the social environment. Thus, malemale interactions would stimulate the production of androgens and the levels of androgens would be a function of the stability of the social environment in which the animal was at that time. This hypothesis was first proposed by Wingfield (1984a,b) and is currently known as the 'challenge hypothesis' (see also Wingfield et al., 1987, 1990). The challenge hypothesis postulates that at the beginning of the breeding season androgen levels rise from a non-breeding baseline to a higher breeding baseline that is sufficient for reproduction (i.e. gametogenesis, the expression of secondary sexual characters, and the performance of reproductive behaviour). In response to environmental stimuli such as male-male interactions and the presence of receptive females, androgen levels can further increase until they reach a maximum physiological level.

This hypothesis has the merit of creating a conceptual framework for the study of social modulation of androgen levels in vertebrates. A number of predictions can, thus, be generated from the challenge hypothesis (Wingfield et al., 1990, 2000). In the present paper some of the predictions of the challenge hypothesis will be revisited using the available data to test its validity in teleost fish. This will be followed by a discussion of the evolutionary implications of the challenge hypothesis.

\section{Androgen levels, territorial intrusions and social status acquisition}

A first prediction of the challenge hypothesis is that during territory establishment the levels of androgens should be higher than in the subsequent phase of territoriality when the territories are already established (Hegner and Wingfield, 1987a; 
Table 1

Comparison of androgen levels between territorial/dominant and non-territorial/subordinate males of different teleost species

\begin{tabular}{|c|c|c|c|c|}
\hline Species (Family) & $\begin{array}{l}\text { Study type } \\
\text { (field vs. lab) }\end{array}$ & Testosterone & 11-Ketotestosterone & Author \\
\hline $\begin{array}{l}\text { Sparisoma viride } \\
\text { (Scaridae) }\end{array}$ & Field & $\mathrm{T}>\mathrm{NT}$ & $\mathrm{T}>\mathrm{NT}$ & Cardwell and Liley, 1991 \\
\hline $\begin{array}{l}\text { Oreochromis mossambicus } \\
\text { (Cichlidae) }\end{array}$ & $\begin{array}{l}\text { Lab (group } \\
\text { formation) }\end{array}$ & $\mathrm{D}>\mathrm{S}$ & $\mathrm{D}>\mathrm{S}$ & Oliveira et al., 1996 \\
\hline $\begin{array}{l}\text { Tilapia zilli } \\
\text { (Cichlidae) }\end{array}$ & $\begin{array}{l}\text { Lab (dyadic } \\
\text { encounters) }\end{array}$ & $\mathrm{D}=\mathrm{S}$ & $\mathrm{D}=\mathrm{S}$ & Neat and Mayer, 1999 \\
\hline $\begin{array}{l}\text { Haplochromis burtoni } \\
\text { (Cichlidae) }\end{array}$ & Lab (groups) & $\mathrm{T}>\mathrm{NT}$ & $\mathrm{T}>\mathrm{NT}$ & Francis and Fernald, 1993 \\
\hline $\begin{array}{l}\text { Xiphophorus helleri } \\
\text { (Poeciliidae) }\end{array}$ & $\mathrm{Lab}$ & $\mathrm{D}=\mathrm{S}$ & ND & $\begin{array}{l}\text { Hannes, } 1984 ? \\
\text { Hannes, } 1986\end{array}$ \\
\hline $\begin{array}{l}\text { Oncorhynchus mykiss } \\
\text { (Salmonidae) }\end{array}$ & $\begin{array}{l}\text { Lab (spawning } \\
\text { groups) }\end{array}$ & $\mathrm{D}>\mathrm{S}$ & $\mathrm{D}>\mathrm{S}$ & Liley and Kroon, 1995 \\
\hline $\begin{array}{l}\text { Onchorhynchus mykiss } \\
\text { (Salmonidae) }\end{array}$ & Lab (small groups) & $\mathrm{D}>\mathrm{S}$ & ND & Cardwell et al., 1996 \\
\hline $\begin{array}{l}\text { Salmo trutta } \\
\text { (Salmonidae) }\end{array}$ & Field & $\mathrm{D}>\mathrm{S}$ & $\mathrm{D}=\mathrm{S}$ & Cardwell et al., 1996 \\
\hline $\begin{array}{l}\text { Salvelinus fontinalis } \\
\text { (Salmonidae) }\end{array}$ & Field & $\mathrm{D}=\mathrm{S}$ & $\mathrm{D}=\mathrm{S}$ & Cardwell et al., 1996 \\
\hline $\begin{array}{l}\text { Salvelinus alpinus } \\
\text { (Salmonidae) }\end{array}$ & Lab (dyadic encounters) & $\mathrm{D}>\mathrm{S}$ & $\mathrm{D}>\mathrm{S}$ & Elofsson et al., 2000 \\
\hline
\end{tabular}

$\mathrm{T}$, territorial; NT, non-territorial; D, dominant; $\mathrm{S}$, subordinate. $>$, indicates significantly higher hormone levels; $=$, indicates no significant differences in hormone levels; ND, not determined.

Wingfield et al., 1990). Moreover, since territorial/dominant males have to defend their territories it would also be expected that they will have higher androgen levels than non-territorial/subordinate males, which do not have to defend their social status.

In teleost fish we are aware of only one study where the effects of experimental territorial intrusions on androgen levels have been tested. In a natural population of the stoplight parrotfish (Sparisoma viride) Cardwell and Liley (1991) found that peaks of androgens could be induced in established territorial males by experimental intrusions of other males. Nevertheless, the prediction that territorial intrusions increase androgen levels can also be tested indirectly by comparing breeding populations of the same species but with different densities, since the probability of a territorial male suffering a territorial intrusion should be higher in more dense populations. This extended prediction should be taken with caution since there may be situations where the increase in population density is accompanied by the expression of mechanisms to avoid aggression. In any case, a positive correlation between density of breeding territories, the number of agonistic interactions and higher levels of androgens has already been demonstrated both in birds and teleosts (birds: Ball and Wingfield, 1987; Beletsky et al., 1990, 1992; teleosts: Pankhurst and Barnett, 1993; Oliveira et al., 2001c).

There are more studies available on the relationship between social status and androgen levels in male teleosts. As a general rule these studies show that territorial/dominant individuals have higher androgen levels than non-territorials/subordinates (Table 1).

The causality of the interaction between androgen levels and territoriality/dominance may be viewed in two ways: (a) androgen levels are the predictors of social status; or (b) social status itself is the cause and not the consequence of higher androgen levels. In trying to disentangle these two hypotheses Oliveira et al. (1996) computed correlations between androgen levels and a social dominance index before and after group formation in the cichlid fish Oreochromis mossambicus. The rationale behind this experiment was that if androgen levels are the determining factors of social status acquisition then it would be expected that androgen levels before group formation would be good predictors of the social status that the individuals would acquire after group formation. In 
contrast, if androgen levels were a response to the acquired social status it would be predicted that only after group formation the correlation between androgen levels and social status would be present. Oliveira et al. (1996) found that the latter hypothesis was the one supported by the data, which showed a lack of correlation between the androgen levels (both $\mathrm{T}$ and KT) prior to group formation and the social status achieved, but strong correlations between androgen levels (both T and KT) measured after group formation and the acquired social status.

Thus, the associations found between androgen levels and social status in male teleosts may potentially be explained by the challenge hypothesis, reflecting a more challenging social environment for territorial/dominant males than for non-territorial/subordinate ones. Moreover, androgens do not play an activational role in social status acquisition. Further studies employing temporal correlations or induced social status reversal will be needed to get a clear picture of the causal link between androgens and social status in teleost fish.

In dyadic interactions of the swordtail fish (Xiphophorus helleri) there was an association between some aspects of aggressive behaviour and high levels of androgens (Hannes, 1986). However, when androgen levels of dominant and of subordinate males from a socially stable community tank were compared, a relationship between dominance and androgens was not found (Hannes, 1984). Taken together these two studies are consistent with the suggestion that a causal relationship between androgens and the expression of aggression is only present in periods of social challenge. In conclusion, we would predict that the association between androgen levels and social status should only emerge at periods of social instability and that in stable social groups androgen levels become dissociated from social status.

\section{Trade-off between territoriality and paternal care}

A second prediction of the challenge hypothesis is that male androgen levels above a breeding baseline are incompatible with the expression of paternal care. If high androgen levels occur in response to frequent territorial or social challenges the male had to cope with, the individual would pay off by investing less time into care of off- spring. Therefore, the trade-off between territorial aggressiveness and paternal care seems to be mediated by androgens. This is supported by observations in many monogamous bird species with male parental care where the experimental increase of testosterone in parental males suppresses paternal behaviour and increases aggression (e.g. Silverin, 1980; Hegner and Wingfield, 1987b; Ketterson et al., 1992). Moreover, several studies on the seasonal patterns of biparental/paternal temperate zone birds have shown higher androgen levels at the beginning of the breeding season when territories are being established and when courtship is more intense, than in the subsequent paternal phases (e.g. Wingfield et al., 1987).

We have gathered published androgen data from paternal teleost species in order to compare the (mean) androgen levels at mating with those during parenting phases (Table 2). For all the species included androgen levels dropped during parental care in agreement with the above-mentioned prediction. It may be argued that the drop of androgen levels in the parenting phase is due to physiological changes associated with the end of sperm production. In fact, androgen levels also drop after spawning in a male salmonid, which provides no paternal care (e.g. Liley et al., 1986). However, the trade-off seems to be present even in species in which there is an overlap of the mating and parenting phase as is the case in blenniid species. Blenniids have exclusive paternal care: the males get a first clutch of eggs in their nests and, while guarding and fanning the eggs, keep on courting females. Males that have recently received a clutch in their nest and, thus, are actively parenting have significantly lower androgen levels than other nest-holder males that did not have a female spawning in their nests recently (Oliveira et al., 2001b).

\section{Mating systems and endocrine responsiveness}

A third prediction of the challenge hypothesis is that male androgen patterns during the breeding season should vary among species according to the amount of social interactions the individuals are exposed to. For example, in monogamous species with high levels of paternal care androgen levels may increase above the breeding baseline only when males are challenged by other males or by mating. At other times androgens should remain at the breeding baseline in order to not interfere 
Table 2

Variation in circulating androgen levels (mean values) throughout the breeding season in male teleosts that display paternal care of offspring $^{\mathrm{a}}$

\begin{tabular}{|c|c|c|c|c|}
\hline Species (Family) & Phase & $\begin{array}{l}\text { Testosterone } \\
(\mathrm{ng} / \mathrm{ml})\end{array}$ & $11-\mathrm{KT}(\mathrm{ng} / \mathrm{ml})$ & Author \\
\hline Syngnathus acus & M & 15.2 & 3.6 & Mayer et al., 1993 \\
\hline (Syngnathidae) & $\mathrm{P}$ & 6.4 & 0.9 & \\
\hline Syngnathus typhle & M & 3.2 & 2.4 & Mayer et al., 1993 \\
\hline (Syngnathidae) & $\mathrm{P}$ & 2.0 & 0.9 & \\
\hline Lepomis macrochirus & M & 24 & $55^{\mathrm{a}}$ & Kindler et al., 1989 \\
\hline (Centrarchidae) & $\mathrm{P}$ & 7 & $14^{\mathrm{a}}$ & \\
\hline \multirow[t]{2}{*}{$\begin{array}{l}\text { Chromis dispilus } \\
\quad \text { (Pomacentridae) }\end{array}$} & M & $4-6 ; 9^{b}$ & $49^{\mathrm{b}}$ & $\begin{array}{l}\text { Pankhurst, } 1990 \\
\text { Barnett and Pankhurst, } 1994\end{array}$ \\
\hline & $\mathrm{P}$ & $<1 ; 1.5^{\mathrm{b}}$ & $8^{\mathrm{b}}$ & \\
\hline Hypsypops rubicundus & M & $15^{\mathrm{b}}$ & $22^{\mathrm{b}}$ & Sikkel, 1993 \\
\hline (Pomacentridae) & $\mathrm{P}$ & $9^{b}$ & $7^{b}$ & \\
\hline \multirow[t]{2}{*}{$\begin{array}{l}\text { Lipophrys pholis } \\
\text { (Blenniidae) }\end{array}$} & M & 1.4 & 2.5 & Oliveira and Canario, unpublished \\
\hline & $\mathrm{P}$ & 0.8 & 1.5 & \\
\hline \multirow{2}{*}{$\begin{array}{l}\text { Parablennius sanguinolentus } \\
\text { parvicornis (Blenniidae) }\end{array}$} & M & 15 & 6 & Oliveira et al., 2001b \\
\hline & $\mathrm{P}$ & 8.1 & 2.1 & \\
\hline \multirow{2}{*}{$\begin{array}{l}\text { Sarotherodon melanotheron } \\
\text { (Cichlidae) }\end{array}$} & $\mathrm{M}$ & 22 & ND & Specker and Kishida, 2000 \\
\hline & $\mathrm{P}$ & 1.9 & ND & \\
\hline \multirow{2}{*}{$\begin{array}{l}\text { Porichthys notatus } \\
\quad \text { (Batrachoididae) }\end{array}$} & $\mathrm{M}$ & $0.1^{\mathrm{c}}$ & 11.5 & Knapp et al., 1999 \\
\hline & $\mathrm{P}$ & $0^{\mathrm{d}}$ & $\begin{array}{l}8.1^{\mathrm{e}} \\
0.8^{\mathrm{f}}\end{array}$ & \\
\hline
\end{tabular}

M, mating phase; $\mathrm{P}$, parental phase.

${ }^{a}$ Values obtained 1 day after spawning.

${ }^{\mathrm{b}}$ Values extrapolated from published graphs.

${ }^{\mathrm{c}}$ Median value.

${ }^{\mathrm{d}}$ No males had detectable values (assay sensitivity was approx. $0.2 \mathrm{ng} / \mathrm{ml}$ ).

${ }^{\mathrm{e}}$ Levels of males guarding nests containing only eggs.

${ }^{\mathrm{f}}$ Levels of males guarding nests with embryos.

with paternal care. Conversely, in males from polygynous species androgen levels should be elevated close to the physiological maximum throughout the breeding season due to high levels of male-male competition. Wingfield et al. (1990) reviewed the available testosterone and aggression data of 20 free-living passeriform species and their results supported the interspecific predictions of the challenge hypothesis. Males of polyandrous and of monogamous species showed higher androgen responsiveness (increase from breeding baseline to maximum response) to social interactions than males of polygynous species. More recently, Wingfield et al. (2000) have increased the number of bird species in their database (60 species) and the resulting patterns remain the same.

This relationship between mating strategies, degree of paternal care and androgen levels is further supported by the fact that $\mathrm{T}$ implanted males of a monogamous species became polygynous, deserting their mates (Wingfield, 1984b). Moreover, males of polygynous species have longer periods of elevated testosterone levels, which correspond to the mating phase (i.e. displaying, mate-guarding, territoriality, etc.; Beletsky et al., 1995).

In order to assess if this is a specific rule in birds or if it also applies to other vertebrates, we have been collecting the available published data to compare the androgen responsiveness patterns between teleost fish species. Below we will present a preliminary analysis of our database at its current status (Figs. 1 and 2). We have separated the effects of the mating system from the effects of the parenting system, which were combined in the analyses mentioned above (Wingfield et al., 1990, 2000). The reason to separate the two factors is twofold. First, in some species with which we are 


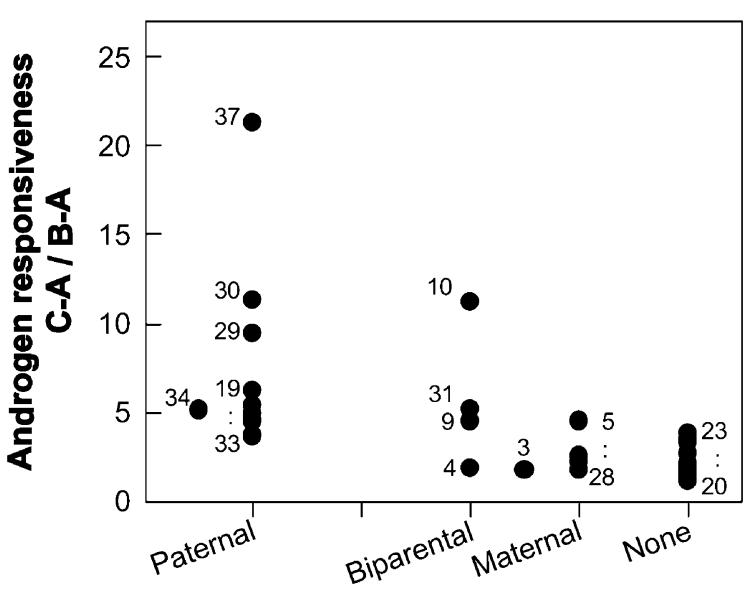

Fig. 1. Androgen responsiveness of male teleost fish for different parental strategies obtained from a literature survey. Androgen responsiveness was calculated as the ratio of the maximum response over the breeding baseline. (a) Non-breeding baseline level; (b) breeding baseline level; (c) maximum physiological response level (Wingfield et al., 1990). Numbers refer to the following species: 1, Acipenser ruthenus (Mojazi Amiri et al., 1996); 2, Oncorhynchus mykiss (Rouger and Liley, 1993); 3, Oncorhynchus nerka (Kubokawa et al., 1999); 4, Salmo salar (Mayer et al., 1990b); 5, Salmo trutta (Cardwell et al., 1996); 6, Salvelinus fontinalis (Cardwell et al., 1996); 7, Cyprinus carpio (Nikitina and Godovich, 1984); 8, Catostomus commersoni (Scott et al., 1984); 9, Ictalurus nebulosus (Rosenblum et al., 1987); 10, Heteropneustes fossilis (Lamba et al., 1983); 11, Fundulus heteroclitus (Cochran, 1987); 12, Porychthys notatus (Knapp et al., 1999); 13, Gasterosteus aculeatus (Mayer et al., 1990a); 14, Syngnathus acus (Mayer et al., 1993); 15, Syngnathus typhle (Mayer et al., 1993); 16, Lates calcarifer (Guiguen et al., 1993); 17, Dicentrarchus labrax (Prat et al., 1990); 18, Morone saxatilis (Mylonas et al., 1997); 19, Lepomis macrochirus (Kindler et al. 1989); 20, Stizostedion vitreum (Malison et al., 1994); 21, Pomatomus saltator (MacGregor et al., 1981); 22, Pagrus major (Ouchi et al., 1988); 23, Acanthopagrus butcheri (Haddy and Pankhurst, 1998); 24, Rhabdosargus sarba (Yeung and Chan, 1987); 25, Sparidentex hasta (Lone et al., 1991); 26, Cynoscion nebulosus (Thomas et al., 1982); 27, Oreochromis aureus (Mol et al., 1994); 28, Oreochromis mossambicus (Oliveira et al., 1996); 29, Sarotherodon melanotheron (Kishida and Specker, 2000); 30, Chromis dispilus (Pankhurst, 1990); 31, Acanthochromis polyacanthus (Haddy and Pankhurst, 1998); 32, Hypsypops rubicundus (Sikkel, 1993); 33, Sparisoma viridae (Cardwell and Liley, 1991); 34, Parablennius sanguinolentus parvicornis (Oliveira et al., 2001b); 35, Salaria pavo (Oliveira et al., 2001a); 36, Scomberomorus cavalla (MacGregor et al., 1981); 37, Trichogaster trichopterus (Degani, 1993); 38, Pleuronectes americanus (Harmin et al., 1995); 39, Pleuronectes platessa (Wingfield and Grimm, 1977); 40, Rhombosolea tapirina (Barnett and Pankhurst, 1999).

less familiar it would be easier to treat the two variables separately than trying to get a combined score. Second, it would allow us to further disen- tangle the specific contributions of each of the two variables to the variation of androgen responsiveness in the different species.

The results confirm the interspecific predictions that the androgen responsiveness is higher in males from paternal species than in males from species without male parental care (linear regression of $\log _{10}$-transformed data: $r=0.5 ; F=4.7$; d.f. $=2$; $P=0.016$; single effect of degree of paternal care: $t=-2.7 ; n=40 ; P=0.011$; Fig. 1$)$. However, so far, we have found no effect of the mating strategy on male androgen responsiveness $(t=0.5 ; n=40$; $P=0.605$; Fig. 2). To verify if the divergence between the results obtained for mating and parenting types was also present in birds but masked by the fact that Wingfield et al. $(1990,2000)$ used a compound measure of both variables, we reanalysed the available avian data from the literature (73 species, Hirschenhauser and Oliveira, 2000). This re-analysis showed that each of the two variables did show a significant association with male androgen responsiveness, in the same way as when only the compound measure is used. Thus, one major difference identified so far between vertebrate taxa is that in teleosts, but not in birds, the parenting system is determining the androgen responsiveness of males rather than the mating strategy. These results may still suffer from the limited availability of specific mating and parenting systems, with promiscuity and paternal care

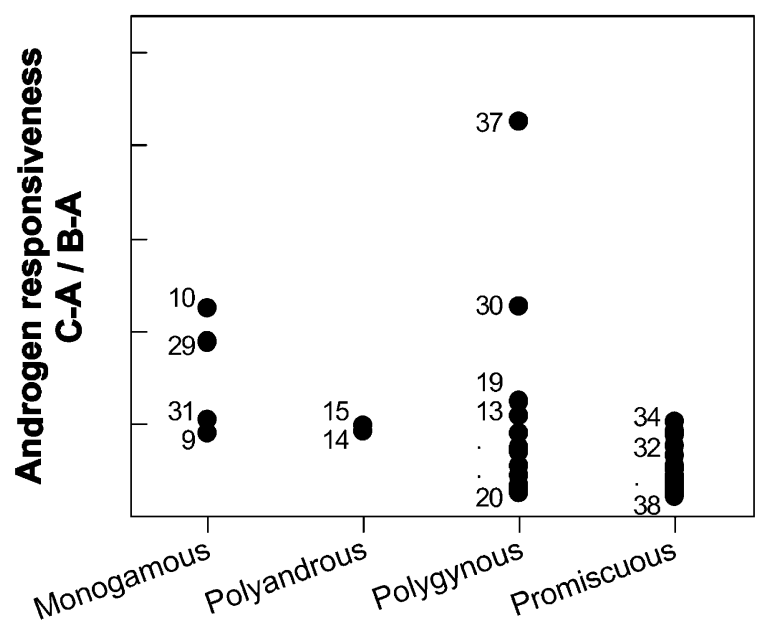

Fig. 2. Androgen responsiveness (Wingfield et al., 1990) of male teleost fish with different mating strategies, as obtained from a literature survey. For the definition of androgen responsiveness refer to legend of Fig. 1. Numbers indicate different species (see also Fig. 1). 


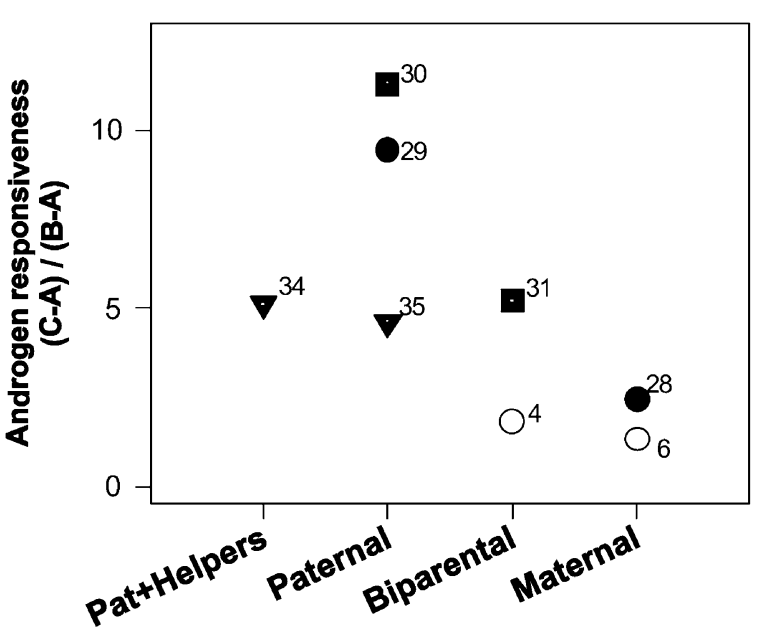

Fig. 3. Pairwise comparisons of male androgen responsiveness (Wingfield et al., 1990) between closely related species with different degrees of paternal investment among four teleost families. Salmonidae: Salmo salar and Salvelinus fontinalis, open squares; Blenniidae: Salaria pavo and Parabelnnius sanguinolentus parvicornis, filled triangles; Cichlidae: Oreochromis mossambicus and Sarotherodon melantheron, filled circles; Pomacentridae: Acantochromis polyacanthus and Chromis dispilus, filled squares. See Fig. 1 for the definition of androgen responsiveness and for the references of the different species (indicated by the numbers).

dominating the available fish species as compared with monogamy and biparental care among avian species. We observed a relatively high variation among polygynous and paternal teleost species, however, the general pattern seems to be relatively robust.

Both our analysis and the analysis of Wingfield et al. $(1990,2000)$ suffer from the problem of a potential phylogenetic bias in the data sets used, for example the over-representation of species from some groups as compared with more rarely studied species from other groups, a problem which has also been recognised by Wingfield et al. (2000). As a first approach to solve this problem we have employed pair-wise comparisons of androgen responsiveness between closely related species that differ in their mating/parenting styles (Fig. 3). These preliminary results show that for all the pairs considered so far, which include species from four different families (salmonidae, blenniidae, cichlidae, and pomacentridae), the results confirm the prediction that in species with paternal care male androgen responsiveness is higher than in species with biparental or maternal care (Fig. 3).
Although the results obtained so far are clear, the pairwise comparison method involves disadvantages, as the selection of the closely related species to be compared may be arbitrary in multilineal evolutionary operation units (e.g. families represented by more than two species). Therefore, we are still gathering more data for this database and a more definitive and inclusive analysis is in progress. Since Wingfield's (Wingfield et al., 1990, 2000) survey of avian endocrine responses to social interactions the challenge hypothesis has inspired a number of more restricted studies on specific groups or species (e.g. Emerson and Hess, 1996; Cavigelli and Pereira, 2000; Nunes et al., 2000; Goymann et al., in press; but see Creel et al., 1993), which in general support it. However, a wider synthesis of the challenge hypothesis across the different vertebrate taxa is still lacking.

\section{The adaptive value of androgen social mod- ulation: androgens as mediators of the social modulation of cognitive processes}

So far we have presented data that in general supports the predictions of the challenge hypothesis in teleost fish, suggesting that social modulation of androgens is a widespread phenomenon in vertebrates including teleost fish. One obvious question that can be raised is why should animals raise their androgen levels in socially challenging environments?

One potential adaptive value of increased androgen levels during periods of social challenge would be a positive effect of androgens on cognitive tasks that would increase the probability of success of animals in social interactions. Animals can use information from previous interactions to adjust their behaviour in subsequent social interactions (e.g. winner-loser effect, Chase et al., 1994; eavesdropping, Oliveira et al., 1998; audience effects, Doutreland et al., 2001) and androgens are good candidates to act as mediators of these effects through modulation of cognitive mechanisms underlying animal communication.

In other vertebrate taxa it is well established that sex steroids play a major role in cognitive processes such as social attention, learning, and memory (see, e.g. Andrews, 1991; Cynx and Nottebohm, 1992), and the neuroendocrine mechanisms underlying these processes are beginning to be revealed. For example, androgen and oestrogen receptors and aromatase activity have been 
detected in the hippocampus of mammals and birds (Gahr et al., 1993; Kerr et al., 1995; Weiland et al., 1997; Saldanha et al., 1999), a brain area known to be involved in relational memory processes (e.g. declarative memory, Eichenbaum et al., 1992; Squire, 1992). Interestingly also in fish androgen receptors have been found in the dorsolateral telencephalon (Gelinas and Callard, 1997) which has recently been demonstrated to be involved in spatial memory formation in goldfish (Vargas et al., 2000).

We have recently tested the effects of androgens on social attention in the Siamese fighting fish (Oliveira and Carneiro, unpublished data). A tank was divided in three parts: a large central compartment, and two smaller end compartments. A male was placed in the central compartment and a pair of males was placed in each of the end compartments. The members of one of the pairs were separated by an opaque partition and the members of the other pair were separated by a clear partition. Thus, in the former pair, males were resting in their individual compartments while in the latter pair, males were displaying to their partner across the clear partition. This set-up has been used in a previous experiment in which it was shown that male Siamese fighting fish spend more time observing the interacting pair and that they use the information they have gathered while eavesdropping in subsequent interactions with individuals they have observed fighting (Oliveira et al., 1998). Thus, the time spent observing conspecifics was used as a measure of social attention. The time that the focal male (placed in the central compartment) spent observing the interacting pair was significantly higher in T-treated fish than in controls, suggesting an effect of $\mathrm{T}$ on social attention. It could be argued that this difference would be a result of increased aggressive motivation in the T-treated fish. However, $\mathrm{T}$ treated subjects did not display higher levels of agonistic behaviour towards the interacting pair than the control group (Oliveira and Carneiro, unpublished data). It is suggested that $\mathrm{T}$ may possibly promote information gathering on the competitive abilities of conspecific neighbours which they can use in future interactions with their neighbours. Hence, we predicted that even the endocrine system of individuals that are not participating directly in a social interaction but are exposed to it - bystanders that can be potential eavesdroppers - should respond to the social environment.
To test this idea we conducted an experiment in which a bystander fish (male $O$. mossambicus) was allowed to observe through a one-way mirror two conspecific neighbours fighting. As predicted androgen levels of bystanders raised after observing fights, but not those of bystanders that were observing conspecifics which were prevented from fighting (Oliveira et al., 2001c). Thus, being exposed to a socially unstable environment may affect the androgen levels of males even if they are not directly involved in the social interactions. The adaptive value of elevated androgen levels in spectators are suggested to be related to the fact that androgens mediate the changes required for increased awareness and readiness to a challenge, which would be more probable to a bystander in a socially unstable environment. Thus, androgens should be viewed not only as sex steroids but also as 'competition' hormones that respond to the social environment and that prepare the individual to face competitive contexts, in the same way that corticosteroids are viewed as stress hormones.

\section{Ultimate consequences of androgen social modulation}

The occurrence of social modulation of androgen levels has some potential implications at the evolutionary level.

First, the expression of androgen-dependent secondary sex characters, both morphological (e.g. ornaments) and behavioural (e.g. courtship), would be expected to be regulated according to their resource holding potential (RHP sensu Parker, 1974 , i.e. their ability to compete successfully with other individuals for a given limited resource) since males have their androgen levels shaped by their social status and social environment. In a social system in which male-male agonistic interactions are frequent, males that display characters that do not correspond to their RHP may incur heavy costs by provoking agonistic confrontations that they will not be able to win. Thus, androgendependent ornaments and behaviours are expected to be honest signals of male quality.

Second, by signalling their status both morphologically and behaviourally, dominant males may reinforce their social status by a positive feedback mechanism. Thus, small initial differences in RHP may result in increasingly larger status differences. This way social modulation of androgens may 
allow the evolution of an amplifier mechanism in signals that are androgen-dependent.

Third, if the beneficial effects of androgens could be separated from their detrimental effects, they would be better mediators of the expression of sexually selected traits. The dissociation of the response of the different trait responses to androgens may be achieved by a local modification of the number or the affinity of steroid receptors present. This would allow a compartmentalisation of the androgen effects on the phenotype (Ketterson and Nolan, 1994). Results compatible with this compartmentalisation mechanism have been observed in cichlid fish in which the relative size of the genital papillae (an indicator of androgen levels) was well correlated with the relative size of the dorsal and anal fins, which are used in male-male competition for mates and in courtship displays towards females. In contrast, the relative size of the genital papillae was not correlated with the relative size of the caudal fin, whose role in reproductive behaviours is constrained by its propulsive function (Oliveira and Almada, 1995, 1998).

Finally, if hormones play a mediating role between the outcomes of social interactions and the expression of male traits, this opens a way for the evolution of a number of alternative life history patterns. In fact, it is known that the social status of a fish may affect a number of its life-history traits such as sexual maturation (e.g. Xiphophorus variatus, Borowsky, 1973, 1978; Astatotilapia burtoni, Fraley and Fernald, 1982), the adoption of alternative male tactics (see Taborsky, 1994 for a review), or even sex-change (see Shapiro, 1979 and Grober, 1998 for general reviews on the subject). All these possibilities may allow compensatory responses to evolve so that subordinate fishes minimise the disadvantages of their status by adopting the life history pattern that makes the best of their situation. For example, a smaller subordinate individual may delay or suspend its sexual maturation and, thereby, may divert more resources to growth, subsequently overcoming its relative size disadvantage. The same compensatory principle has also been proposed both, for alternative mating tactics (e.g. Taborsky, 1994; Gonçalves et al., 1996) and for socially controlled mechanisms of sex-change (e.g. Warner, 1975; Warner et al., 1975). This phenomenon may be much more widespread among teleosts, as it is much less conspicuous than sex change or the adoption of sneaking tactics, and requires specific ontogenetic studies for it to be revealed.

\section{Conclusions}

In summary we have presented data confirming the occurrence of social modulation of androgen levels in teleosts. Furthermore, the predictions of the 'challenge hypothesis' (Wingfield et al., 1990) regarding the effects of the mating system and of the parenting style on androgen responsiveness were confirmed, especially for the latter. Thus, the 'challenge hypothesis' (Wingfield et al., 1990), which has been initially proposed for avian species, may emerge as a general principle in vertebrate endocrinology.

\section{Acknowledgments}

This work was funded by Fundação para a Ciência e a Tecnologia (Praxis/P/BIA/10251/ 1998). The authors wish to thank John Wingfield, Vitor Almada and Albert Ros for stimulating discussions on this topic. The following people contributed either with data or with valuable information for the analysis: Alexis Dujmic, David Gonçalves, Emanuel Gonçalves, Ned Pankhurst, Ricardo Beldade, and Ricardo Matos.

\section{References}

Andrews, R.J., 1991. Testosterone, attention and memory. In: Bateson, P. (Ed.), The Development and Integration of Behaviour. Cambridge University Press, Cambridge, pp. 171-190.

Ball, G.F., Wingfield, J.C., 1987. Changes in plasma luteinizing hormone and sex steroid hormones in relation to multiplebroodedness and nest-site density in male starlings. Physiol. Zool. 602, 191-199.

Barnett, C.W., Pankhurst, N.W., 1994. Changes in plasma levels of gonadal steroids, gonad morphology during the spawning cycle of male, female demoiselles Chromis dispilus (Pisces: Pomacentridae). Gen. Comp. Endocrinol. 93, 260-274.

Barnett, C.W., Pankhurst, N.W., 1999. Reproductive biology and endocrinology of greenback flounder Rhombosolea tapirina (Günther 1862). Mar. Freshwater Res. 50, 35-42.

Beletsky, L.D., Gori, D.F., Freeman, S., Wingfield, J.C., 1995. Testosterone and polygyny in birds. In: Power, D.M. (Ed.), Current Ornithology, Vol. 12. Plenum Press, NY, pp. 1-41.

Beletsky, L.D., Orians, G.H., Wingfield, J.C., 1990. Steroid hormones in relation to territoriality, breeding density, and parental behavior in male yellow-headed blackbirds. Auk 107, 60-68.

Beletsky, L.D., Orians, G.H., Wingfield, J.C., 1992. Year-toyear patterns of circulating levels of testosterone and corticosterone in relation to breeding density, experience, and reproductive success of the polygynous red-winged blackbird. Horm. Behav. 26, 420-432. 
Booth, A., Shelley, G., Mazur, A., Tharp, G., Kittok, R., 1989. Testosterone, and winning and losing in human competition. Horm. Behav. 23, 556-571.

Borges, R.A., Oliveira, R.F., Almada, V.C., Canário, A.V.M., 1998. Short-term social modulation of 11-ketotestosterone urinary levels in males of the cichlid fish Oreochromis mossambicus during male-female interaction. Acta Ethol. $1,43-48$.

Borowsky, R., 1973. Social control of adult size in males of Xiphophorus variatus (Pisces: Poecilidae). Nature 245, 933-935.

Borowsky, R., 1978. Social inhibition of maturation in natural populations of Xiphophorus variatus (Pisces: Poecilidae). Science 201, 933-935.

Cardwell, J.R., Liley, N.R., 1991. Androgen control of social status in males of a wild population of stoplight parrotfish, Sparisoma viride (Scaridae). Horm. Behav. 25, 1-18.

Cardwell, J.R., Sorensen, P.W., Van der Kraak, G.J., Liley, N.R., 1996. Effect of dominance status on sex hormone levels in laboratory and wild-spawning male trout. Gen. Comp. Endocrinol. 101, 333-341.

Cavigelli, S., Pereira, M.E., 2000. Mating aggression and fecal testosterone levels in male ring-tailed lemurs (Lemur catta). Horm. Behav. 37, 246-255.

Chase, I.D., Bartolomeo, C., Dugatkin, L., 1994. Aggressive interactions and inter-contest interval: how long do winners keep winning? Anim. Behav. 48, 393-400.

Cochran, R.C., 1987. Serum androgens during the annual reproductive cycle of the male mummichog, Fundulus heteroclitus. Gen. Comp. Endocrinol. 65, 141-148.

Creel, S., Wildt, D.E., Monfort, S.L., 1993. Aggression, reproduction, and androgens in wild dwarf mongooses: a test of the challenge hypothesis. Am. Nat. 141, 816-825.

Cynx, J., Nottebohm, F., 1992. Testosterone facilitates some conspecific song discriminations in castrated zebra finches (Taeniopygia guttata). Proc. Natl. Acad. Sci. USA 89, 1376-1378.

Degani, G., 1993. Effect of sexual behavior on oocyte development and steroid changes in Trichogaster trichopterus (Pallas).. Copeia 4, 1091-1096.

Dittami, J.P., Reyer, H.-U., 1984. A factor-analysis of seasonal behavioural, hormonal and body-weight changes in adult male bar-headed geese, Anser indicus. Behaviour 90, 114-124.

Doutreland, C., McGregor, P.K., Oliveira, R.F., 2001. The sex of an audience affects intra-sexual male communication in fighting fish, Betta splendens. Behav. Ecol. 12, 283-286.

Eberhart, J.A., Keverne, E.B., Meller, R.E., 1980. Social influences on plasma testosterone levels in male Talapoin monkeys. Horm. Behav. 14, 247-266.

Eichenbaum, H., Otto, T., Cohen, N.J., 1992. The hippocampus: what does it do? Behav. Neural Biol. 57, 2-36.

Elofsson, U.O., Mayer, I., Damsgård, B., Winberg, S., 2000. Intermale competition in sexually mature arctic charr: effects on brain monoamines, endocrine stress responses, sex hormone levels, and behavior. Gen. Comp. Endocrinol. 118, $450-460$.

Emerson, S.B., Hess, D.L., 1996. The role of androgens in opportunistic breeding tropical frogs. Gen. Comp. Endocrinol. 103, 220-230.
Falter, U., Dolisy, D., 1989. The effects of female sexual pheromones on the behaviour of Oreochromis niloticus, $O$. mossambicus and hybrid males (Pisces: Cichlidae). Ann. Kon. Mus. Mid. Afrika Zool. Wetensch. 257, 35-38.

Fraley, N.B., Fernald, R.D., 1982. Social control of developmental rate in the African cichlid, Haplochromis burtoni. Z. Tierpsychol. 60, 66-82.

Francis, R.C., Fernald, R.D., 1993. Neuroendocrine effects of dominance status in an African cichlid. XXIII International Ethological Conference (Torremolinos, Spain) Abstracts, 340.

Gahr, M., Guttinger, H.-R., Kroodsma, D.E., 1993. Estrogen receptors in the avian brain: survey reveals general distribution and forebrain areas unique to songbirds. J. Comp. Neurol. 327, 112-122.

Gelinas, D., Callard, G.V., 1997. Immunolocalization of aromatase- and androgen receptor-positive neurons in the goldfish brain. Gen. Comp. Endocrinol. 106, 155-168.

Gonçalves, E.J., Almada, V.C., Oliveira, R.F., Santos, A.J., 1996. Female mimicry as a mating tactic in males of the blenniid fish Salaria pavo. J. Mar. Biol. Assoc. UK 76, 529-538.

Goymann, W., East, M., Hofer, H., in press. Association with females, but not social status, predicts plasma androgen levels in male spotted hyenas. Behav. Ecol. Sociobiol.

Greenberg, N., Crews, D., 1990. Endocrine and behavioural responses to aggression and social dominance in the green anole lizard, Anolis carolinensis. Gen. Comp. Endocrinol. 77, 246-255.

Grober, M.S., 1998. Socially controlled sex change: integrating ultimate and proximate levels of analysis. Acta Ethol. 1, 3-17.

Guiguen, Y., Jalabert, B., Thouart, E., Fostier, A., 1993. Changes in plasma and gonadal steroid hormones in relation to the reproductive cycle and the sex inversion process in the protandrous seabass, Lates calcarifer. Gen. Comp. Endocrinol. 92, 327-338.

Haddy, J.A., Pankhurst, N.W., 1998. Annual change in reproductive condition and plasma concentrations of sex steroids in black bream, Acanthopagrus butcheri (Munro) (Sparidae). Mar. Freshwater Res. 49, 389-397.

Hannes, R.P., 1984. Androgen and corticoid levels in blood and body extracts of high and low ranking swordtail males (Xiphophorus helleri) before and after social isolation. Z. Tierpsychol. 66, 70-76.

Hannes, R.P., 1986. Blood and whole-body androgen levels of male swordtails correlated with aggression measures in a standard-opponent test. Aggress. Behav. 12, 249-254.

Harding, C.F., 1981. Social modulation of circulating hormone levels in the male. Am. Zool. 21, 223-231.

Harding, C.F., Follett, B.K., 1979. Hormone changes triggered by aggression in a natural population of blackbirds. Science 203, 918-920.

Harmin, S.A., Crim, L.W., Wiegand, M.D., 1995. Plasma sex steroid profiles and the seasonal reproductive cycle in male and female winter flounder, Pleuronectes americanus. Mar. Biol. 121, 601-610. 
Hegner, R.E., Wingfield, J.C., 1987a. Social status and circulating levels of hormones in flocks of house sparrows, Passer domesticus. Ethology 76, 1-14.

Hegner, R.E., Wingfield, J.C., 1987b. Effects of experimental manipulations of testosterone levels on parental investment and breeding success in male house sparrows. Auk 104, 462-469.

Hirschenhauser, K., Oliveira, R.F., 2000. The 'challenge hypothesis' revisited: a meta-analysis. Trabajos Inst. Cajal 77, 305-306.

Kerr, J.E., Allore, R.J., Beck, S.G., Handa, R.J., 1995. Distribution and hormonal regulation of androgen receptors (AR) and AR messenger ribonucleic acid in the rat hippocampus. Endocrinology 136, 3213-3221.

Ketterson, E.D., Nolan, V., 1994. Hormones and life histories: An integrative approach. In: Real, L.A. (Ed.), Behavioral Mechanisms in Evolutionary Ecology. Univ. Chicago Press, Chicago, pp. 327-353.

Ketterson, E.D., Nolan, V., Wolf, L., Ziegenfus, C., 1992. Testosterone and avian life histories: effects of experimentally elevated testosterone on behavior and correlates of fitness in the dark-eyed junco, Junco hyemalis. Am. Nat. 140, 980-999.

Kindler, P.M., Philipp, D.P., Gross, M.R., Bahr, J.M., 1989. Serum 11-ketotestosterone and testosterone concentrations associated with reproduction in male bluegill (Lepomis macrochirus: Centrarchidae). Gen. Comp. Endocrinol. 75, 446-453.

Kishida, M., Specker, J.L., 2000. Paternal mouthbrooding in the black-chinned tilapia, Sarotherodon melanotheron (Pisces: Cichlidae): Changes in gonadal steroids and potential for vitellogenin transfer to larvae. Horm. Behav. 37, 40-48.

Knapp, R., Wingfield, J.C., Bass, A.H., 1999. Steroid hormones and paternal care in the plainfin midshipman fish (Porichthys notatus). Horm. Behav 35, 81-89.

Kubokawa, K., Watanabe, T., Yoshioka, M., Iwata, M., 1999. Effects of acute stress on plasma cortisol, sex steroid hormone and glucose levels in male and female sockeye salmon during the breeding season. Aquaculture 172, 335-349.

Lamba, V.J., Goswami, S.V., Sundaraj, B.I., 1983. Circannual and circadian variations in plasma levels of steroids (cortisol, estradiol-17b, estrone, and testosterone) correlated with the annual gonadal cycle in the catfish, Heteropneustes fossilis (Bloch). Gen. Comp. Endocrinol. 50, 205-225.

Liley, N.R., Breton, B., Fostier, A., Tan, E.S.P., 1986. Endocrine changes associated with spawning behavior and social stimuli in a wild population of rainbow trout Salmo gairdneri. I. Males. Gen. Comp. Endocrinol. 62, 145-156.

Liley, N.R., Olsén, K.H., Foote, C.J., van der Kraak, G.V., 1993. Endocrine changes associated with spawning behavior in male kokanee salmon Oncorhynchus nerka, the effects of anosmia. Horm. Behav. 27, 470-487.

Liley, N.R., Kroon, F.J., 1995. Male dominance, plasma hormone concentrations, and availability of milt in male rainbow trout (Oncorhynchus mykiss). Can. J. Zool. 73, 826-836.

Logan, C.A., Wingfield, J.C., 1990. Autumnal territorial aggression is independent of plasma testosterone in mockingbirds. Horm. Behav. 24, 568-581.
Lone, K.R., Al-Marzouk, A., Kime, D.E., 1991. Seasonal changes in steroids in a protandrous teleost Sparidentex hasta Valenciennes. In: Scott, A.P., Sumpter, J.E., Kime, D.E., Rolfe, M.S. (Eds.), Reproductive Physiology of Fish, Sheffield. pp. 169

MacGregor, R., Dindo, J.J., Finucane, J.H., 1981. Changes in serum androgens and estrogens during spawning in bluefish, Pomatomus saltator, and king mackerel, Scomberomorus cavalla. Can. J. Zool. 59, 1749-1754.

Malison, J.A., Procarione, L.S., Barry, T.P., Kapuscinski, A.R., Kayes, T.B., 1994. Endocrine and gonadal changes during the annual reproductive cycle of the freshwater teleost, Stizostedion vitreum. Fish Physiol. Biochem. 13, 473-484.

Mayer, I., Borg, B., Schulz, R., 1990a. Seasonal changes in and effect of castration/androgen replacement on the plasma levels of five androgens in the male three-spined stickleback, Gasterosteus aculeatus L. Gen. Comp. Endocrinol. 79, 23-30.

Mayer, I., Lundqvist, H., Berglund, I., Schmitz, M., Schulz, R., Borg, B., 1990b. Seasonal endocrine changes in Baltic salmon, Salmo salar, immature parr and mature male parr. I. Plasma levels of five androgens, $17 \alpha$-hydroxy-20 $\beta$-dihydroprogesterone, and $17 \beta$-estradiol. Can. J. Zool. 68, 1360-1365

Mayer, I., Rosenqvist, G., Borg, B., Ahnesjo, I., Berglund, A., Schulz, R., 1993. Plasma levels of sex steroids in three species of pipefish (Syngnathidae). Can. J. Zool. 71, 1903-1907.

Mojazi Amiri, B., Maebayashi, M., Adachi, S., Yamauchi, K., 1996. Testicular development and sex steroid profiles during the annual cycle of the male sturgeon hybrid, the bester. J. Fish Biol. 48, 1039-1050.

Mol, K., Byamungu, N., Cuisset, B., et al., 1994. Hormonal profile of growing male and female diploids and triploids of the blue tilapia, Oreochromis aureus, reared in intensive culture. Fish Physiol. Biochem. 13, 209-218.

Moore, M.C., 1986. Circulating steroid hormones during rapid aggressive responses of territorial male mountain spiny lizards, Scleropus jarrovi. Horm. Behav. 21, 511-521.

Moore, M.C., 1988. Testosterone control of territorial behavior: tonic release implants fully restore seasonal, short-term aggressive responses in free-living castrated lizards. Gen. Comp. Endocrinol. 70, 450-459.

Mylonas, C.C., Scott, A.P., Zohar, Y., 1997. Plasma gonadotropin II, sex steroids, and thyroid hormones in wild striped bass (Morone saxatilis) during spermiation and final oocyte maturation. Gen. Comp. Endocrinol. 108, 223-236.

Neat, F.C., Mayer, I., 1999. Plasma concentrations of sex steroids and fighting in male Tilapia zillii. J. Fish Biol. 54, 695-697.

Nelson, R., 1994. An Introduction to Behavioral Endocrinology. Sinauer Assoc, Saunderland, MA.

Nikitina, M.M., Godovich, P.L., 1984. Dynamics of hormones in the blood of male and female carp, Cyprinus carpio (Cyprinidae), during the spawning period. J. Ichthyol. 23, 118-123.

Nunes, S., Fite, J.E., French, J.A., 2000. Variation in steroid hormones associated with infant care behaviour and experience in male marmosets (Callithrix kuhlii). Anim. Behav. $60,857-865$. 
Oliveira, R.F., Almada, V.C., 1995. Sexual dimorphism and allometry of external morphology in Oreochromis mossambicus. J. Fish Biol. 46, 1055-1064.

Oliveira, R.F., Almada, V.C., 1998. Androgenization of dominant males in a cichlid fish: androgens mediate the social modulation of sexually dimorphic traits. Ethology 104, 841-858.

Oliveira, R.F., Almada, V.C., Canário, A.V.M., 1996. Social modulation of sex steroid concentrations in the urine of male cichlid fish Oreochromis mossambicus. Horm. Behav. $30,2-12$.

Oliveira, R.F., McGregor, P., Latruffe, C., 1998. Know thine enemy: fighting fish gather information from observing conspecifics interactions. Proc. R. Soc. Lond. B 265, 1045-1049.

Oliveira, R.F., Almada, V.C., Gonçalves, E.J., Forsgren, E., Canário, A.V.M., 2001a. Androgen levels and social interactions in breeding males of the peacock blenny (Salaria pavo). J. Fish Biol. 58, 897-908.

Oliveira, R.F., Canário, A.V.M., Grober, M.S., Santos, R.S., 2001b. Endocrine correlates of alternative reproductive tactics and male polymorphism in the Azorean rock-pool blenny, Parablennius sanguinolentus parvicornis. Gen. Comp. Endocrinol. 121, 278-288.

Oliveira, R.F., Lopes, M., Carneiro, L.A., Canário, A.V.M., 2001c. Watching fights raises fish hormone levels. Nature 409, 475.

Ouchi, K., Adachi, S., Nagahama, Y., 1988. Changes in plasma levels of steroid hormones during sexual maturation of male red seabream Pagrus major. Nippon Suisan Gakkaishi 54, 593-597.

Pankhurst, N.W., 1990. Changes in plasma levels of gonadal steroids during spawning behaviour in territorial male demoiselles Chromis dispilus (Pisces: Pomacentridae) sampled underwater. Gen. Comp. Endocrinol. 79, 215-225.

Pankhurst, N.W., Barnett, C.W., 1993. Relationship of population density, territorial interaction, and plasma levels of gonadal steroids in spawning male demoiselles Chromis dispilus (Pisces, Pomacentridae). Gen. Comp. Endocrinol. 90, 168-176.

Parker, G.A., 1974. The assessment strategy and the evolution of fighting behaviour. J. Theor. Biol. 47, 223-243.

Prat, F., Zanuy, S., Carrillo, M., de Mones, A., Fostier, A., 1990. Seasonal changes in plasma levels of gonadal steroids of sea bass, Dicentrarchus labrax L. Gen. Comp. Endocrinol. 78, 361-373.

Rosenblum, P.M., Pudney, J., Callard, I.P., 1987. Gonadal morphology, enzyme histochemistry and plasma steroid levels during the annual reproductive cycle of male and female brown bullhead catfish, Ictalurus nebulosus Lesueur. J. Fish Biol. 31, 325-341.

Rouger, Y., Liley, N.R., 1993. Effect of social environment on plasma hormones and availability of milt in spawning male rainbow trout (Oncorhynchus mykiss Walbaum). Can. J. Zool. 71, 280-285.

Ramenofsky, M., 1984. Agonistic behaviour and endogenous plasma hormones in Japanese quail. Anim. Behav. 32, 698-708.

Sachser, N., Pröve, E., 1984. Short-term effects of residence in the testosterone responses to fighting in male guinea pigs. Aggr. Behav. 10, 285-292.
Saldanha, C.J., Clayton, N.S., Schlinger, B.A., 1999. Androgen metabolism in the juvenile oscine forebrain: a cross-species analysis at neural sites implicated in memory function. J. Neurobiol. 40, 397-406.

Sapolsky, R.M., 1987. Stress, social status, and reproductive physiology in free-living baboons. In: Crews, D. (Ed.), Psychobiology of Reproductive Behavior - An Evolutionary Perspective. Prentice Hall, Englewood Cliffs, NJ, pp. 291-322.

Scott, A.P., MacKenzie, D.S., Stacey, N.E., 1984. Endocrine changes during natural spawning in the white sucker, Catastomus commersoni. I. Steroid Hormones. Gen. Comp. Endocrinol. 56, 349-359.

Shapiro, D.Y., 1979. Social behaviour, group structure, and the control of sex reversal in hermaphroditic fish. Adv. Study Behav. 10, 43-102.

Sikkel, P.C., 1993. Changes in plasma androgen levels associated with changes in male reproductive behavior in a brood cycling marine fish. Gen. Comp. Endocrinol. 89, 229-237.

Silverin, B., 1980. Effects of long-lasting testosterone treatment on free-living pied flycatchers, Ficedula hypoleuca, during the breeding season. Anim. Behav. 218, 906-912.

Silverman, H.I., 1978. Effects of different levels of sensory contact upon reproductive activity of adult male and female Sarotherodon (Tilapia) mossambicus (Peters); Pisces: Cichlidae. Anim. Behav. 26, 1081-1090.

Specker, J.L., Kishida, M., 2000. Mouthbrooding in the blackchinned tilapia, Sarotherodon melanotheron (Pisces: Cichlidae): the presence of eggs reduces androgen and estradiol levels during paternal and maternal behavior. Horm. Behav. $38,44-51$.

Squire, L.R., 1992. Memory and the hippocampus: a synthesis from findings with rats, monkeys, and humans. Psychol. Rev. 9, 195-231.

Taborsky, M., 1994. Sneakers, satellites, and helpers: parasitic and cooperative behavior in fish reproduction. Adv. Study Behav. 23, 1-100.

Thomas, P., Brown, N.J., Arnold, C.R., 1982. Seasonal variations of plasma androgens and gonad histology in male spotted seatrout, Cynoscion nebulosus (Family: Sciaenidae). In: Richter, C.J.J., Goos, H.J.T. (Eds.), Reproductive Physiology of Fish. Centre for Agricultural Publishing and Documentation (Pudoc), Wageningen, pp. 111.

Vargas, J.P., Rodríguez, F., López, J.C., Arias, J.L., Salas, C., 2000. Spatial learning-induced increase in the argyrophilic nuclear organizer region of dorsolateral telencephalic neurons in goldfish. Brain Res. 865, 77-84.

Villars, T.A., 1983. Hormones and aggressive behaviour in teleost fishes. In: Svare, B.B. (Ed.), Hormones and Aggressive Behaviour. Plenum Press, New York, pp. 407-433.

Warner, R.R., 1975. The adaptive significance of sequential hermaphroditism in animals. Am. Nat. 109, 61-82.

Warner, R.R., Robertson, D.R., Leigh, E.G., 1975. Sex change and sexual selection. Science 190, 633-639.

Weiland, N.G., Orikasa, C., Hayashi, S., McEwen, B.S., 1997. Distribution and hormone regulation of estrogen receptor immunoreactive cells in the hippocampus of male and female rats. J. Comp. Neurol. 388, 603-612.

Wingfield, J.C., Grimm, A.S., 1977. Seasonal changes in plasma cortisol, testosterone and oestradiol-17 $\beta$ in the plaice, Pleuronectes platessa L. Gen. Comp. Endocrinol. $31,1-11$. 
Wingfield, J.C., 1984a. Environmental and endocrine control of reproduction in the song sparrow, Melospiza melodia. I: Temporal organization of the breeding cycle. Gen. Comp. Endocrinol. 56, 406-416.

Wingfield, J.C., 1984b. Environmental and endocrine control of reproduction in the song sparrow, Melospiza melodia. II: Agonistic interactions as environmental information stimulating secretion of testosterone. Gen. Comp. Endocrinol. 56, 417-424.

Wingfield, J.C., Ramenofsky, M., 1985. Testosterone and aggressive behaviour during the reproductive cycle of male birds. In: Gilles, R., Balthazart, J. (Eds.), Neurobiology. Springer-Verlag, Berlin, pp. 92-104.

Wingfield, J.C., Moore, M.C., 1987. Hormonal, social, and environmental factors in the reproductive biology of freeliving male birds. In: Crews, D. (Ed.), Psychobiology of
Reproductive Behavior - An Evolutionary Perspective. Prentice Hall, Englewood Cliffs, pp. 291-322.

Wingfield, J.C., Ball, G.F., Dufty, A.M., Hegner, R.E., Ramenofsky, M., 1987. Testosterone and aggression in birds: tests of the challenge hypothesis. Am. Sci. 75, 602-608.

Wingfield, J.C., Hegner, R.E., Dufty, A.M., Ball, G.F., 1990. The 'challenge hypothesis': theoretical implications for patterns of testosterone secretion, mating systems, and breeding strategies. Am. Nat. 136, 829-846.

Wingfield, J.C., Jacobs, J.D., Tramontin, A.D., et al., 2000. Toward an ecological basis of hormone-behavior interactions in reproduction of birds. In: Wallen, K., Schneider, J.E. (Eds.), Reproduction in Context. MIT Press, Cambridge, MA, pp. 85-128.

Yeung, W.S.B., Chan, S.T.H., 1987. A radioimmunoassay study of the plasma levels of sex steroids in the protandrous, sexreversing fish Rhabdosargus sarba (Sparidae). Gen. Comp. Endocrinol. 66, 353-363. 